\title{
Thrombotic and hemorrhagic events in critically ill COVID-19 patients: a French monocenter retrospective study
}

\author{
Megan Fraissé, Elsa Logre, Olivier Pajot, Hervé Mentec, Gaëtan Plantefève and Damien Contou*
}

Keywords: SARS-CoV-2, COVID-19, Thrombosis, Pulmonary embolism, D-dimers, ARDS, Intensive care

\section{Introduction}

Patients admitted to the intensive care unit (ICU) for coronavirus disease 2019 (COVID-19), following an infection by the severe acute respiratory syndrome coronavirus 2 (SARS-CoV-2), seem to have an increased risk of thrombotic events (TE), both arterial and venous [1-3]. Even in the absence of high level of evidence, some centers have consequently modified their pharmacological thromboprophylaxis strategy toward intermediate or full-dose (therapeutic) preemptive anticoagulation (rather than prophylactic dosing) for routine care of COVID-19 patients [2, 4], exposing them to a higher risk of hemorrhagic events (HE).

Our aim was to assess the rates and to describe each TE and HE occurring in critically ill COVID-19 patients admitted to our ICU.

\section{Methods}

We retrospectively analyzed data from patients admitted to our 41-bed COVID-19 ICU between March 6 and April 22, 2020. All patients received usual (prophylactic) or full-dose (therapeutic) anticoagulation according to their risk factors for thrombosis [4]. All TE (venous or arterial) diagnosed during ICU stay were collected, except central venous catheter related thrombosis and hemodialysis filter thrombosis. TE were investigated only in case of clinical suspicion, and not in a routine manner. All significant (interruption of anticoagulation and red blood cell transfusion, surgical intervention or death) HE were collected.

\section{Results}

During the study period, 92 patients were admitted to our ICU for acute respiratory failure related to SARSCoV-2 pneumonia. Main demographic and clinical characteristics are detailed in the Table 1 . At the time of analysis (May 6), 37 of them (40\%) experienced a total of 39 TE including 31 venous (79\%) and 8 arterial (21\%) thrombosis, and 19 of them (21\%) experienced a total of 22 HE during their ICU stay. Distributions of each TE and $\mathrm{HE}$ are detailed in the Fig. 1.

Median days between ICU admission and TE and between first COVID-19 symptoms and TE were 9 [3$21]$ and 17 [12-28], respectively. There was no difference regarding clinical characteristics between patients with or without a TE, except from D-dimer levels and prothrombin time (Table 1). Among patients with an HE, $16(n=16 / 19,84 \%)$ received fulldose anticoagulation, including $8(50 \%)$ without a confirmed TE. All HE required interruption of anticoagulation, 3 (14\%) were fatal 1 (2 intra-cranial, 1 deep muscle), 14 (64\%) required red blood cells transfusion, and $5(24 \%)$ required bronchoscopy or gastroscopy. Only one of the $15(7 \%)$ anti-Xa activity performed the day of HE was overdosed.

\footnotetext{
* Correspondence: damien.contou@ch-argenteuil.fr

Service de réanimation polyvalente, Centre Hospitalier Victor Dupouy, 69, rue du Lieutenant-Colonel Prud'hon, 95100 Argenteuil, France
} 
Table 1 Characteristics of 92 critically ill COVID-19 patients who developed ( $n=37,40 \%)$ or not $(n=55,60 \%)$ a thrombotic event during ICU stay (*at the time of analysis (May 6, 2020); data for 91 patients as one patient was lost to follow-up)

\begin{tabular}{|c|c|c|c|c|}
\hline & $\begin{array}{l}\text { All patients, } \boldsymbol{n}= \\
92\end{array}$ & $\begin{array}{l}\text { Patients without thrombotic events, } \boldsymbol{n}=55 \\
(60 \%)\end{array}$ & $\begin{array}{l}\text { Patients with thrombotic events, } \boldsymbol{n}=37 \\
(40 \%)\end{array}$ & $p$ \\
\hline Age (years) & $61[55-70]$ & $61[55-69]$ & $62[54-71]$ & 0.89 \\
\hline Male, $n(\%)$ & $73(79)$ & $44(80)$ & $29(78)$ & 0.55 \\
\hline Body mass index $\left(\mathrm{kg} / \mathrm{m}^{2}\right)$ & 30 [26-35] & $32[25-36]$ & 29 [27-34] & 0.34 \\
\hline Baseline SOFA & $4[3-7]$ & $4[2-7]$ & $4[3-8]$ & 0.6 \\
\hline Baseline SAPS ॥ & $31[21-40]$ & 31 [20-39] & $31[22-44]$ & 0.8 \\
\hline \multicolumn{5}{|l|}{ Main comorbidities, $n(\%)$} \\
\hline Hypertension & $59(64)$ & $36(65)$ & $23(62)$ & 0.75 \\
\hline Diabetes mellitus & $35(38)$ & $22(40)$ & $13(35)$ & 0.75 \\
\hline Cardio-vascular diseases & $9(10)$ & $8(14)$ & $1(3)$ & 0.48 \\
\hline Atrial fibrillation & $3(3)$ & $1(2)$ & $2(5)$ & 0.06 \\
\hline Cerebro-vascular diseases & $8(9)$ & $5(9)$ & $3(8)$ & 0.34 \\
\hline Venous thrombo-embolism & $5(5)$ & $3(5)$ & $2(5)$ & 0.89 \\
\hline Chronic respiratory diseases & $18(20)$ & $11(20)$ & $7(19)$ & 0.99 \\
\hline Chronic renal failure & $7(8)$ & $7(13)$ & 0 & 0.03 \\
\hline \multicolumn{5}{|c|}{ Laboratory measurements at ICU admission } \\
\hline Fibrinogen ( $g / L)$ & $7.8[6.1-8.8]$ & $7.5[6.0-8.6]$ & 7.9 [6.3-9] & 0.45 \\
\hline D-dimers $(\mu \mathrm{g} / \mathrm{mL})$ & $2.4[1.7-7.9]$ & $2.2[1.2-5.9]$ & $4.4[1.8-2]$ & 0.03 \\
\hline Prothrombin time (\%) & 86 [76-96] & $92[80-100]$ & 79 [68-90] & $\begin{array}{l}< \\
0.001\end{array}$ \\
\hline Platelets (G/L) & 227 [182-307] & $213[170-302]$ & 235 [198-340] & 0.17 \\
\hline \multicolumn{5}{|l|}{ Thromboprophylaxis strategy } \\
\hline $\begin{array}{l}\text { Usual (prophylactic) } \\
\text { anticoagulation }\end{array}$ & $43(47)$ & $26(47)$ & $17(46)$ & 0.90 \\
\hline $\begin{array}{l}\text { Full-dose (therapeutic) } \\
\text { anticoagulation }\end{array}$ & $49(53)$ & $29(53)$ & $20(54)$ & 0.90 \\
\hline \multicolumn{5}{|l|}{ Outcome in ICU, $n$ (\%) } \\
\hline Invasive mechanical ventilation & $82(89)$ & $46(84)$ & $36(97)$ & 0.04 \\
\hline Prone positioning & $55(60)$ & $32(58)$ & $23(62)$ & 0.70 \\
\hline Vasopressor support & $57(62)$ & $31(56)$ & $26(70)$ & 0.18 \\
\hline Renal replacement therapy & $22(24)$ & $11(20)$ & $11(30)$ & 0.28 \\
\hline ICU mortality* & $38(41)$ & $20(36)$ & $18(49)$ & 0.24 \\
\hline Still hospitalized in ICU* & $25(27)$ & $13(24)$ & $12(32)$ & 0.35 \\
\hline Discharged to the wards* & $28(30)$ & $21(38)$ & $7(19)$ & 0.05 \\
\hline
\end{tabular}

Continuous variables were reported as median [Interquartile range] (IQR) and compared between groups using the Mann-Whitney test. Categorical variables were reported as numbers and percentages and compared using $X^{2}$ test or Fisher's exact test, as appropriate. A $p$ value $<0.05$ was considered significant

\section{Discussion}

We herein report on a $40 \%$ rate of TE in critically ill patients with COVID-19, mostly venous TE. This rate is in accordance with previous series $[1,2]$. However, it is lower than the $69 \%$ rate reported by Llitjos et al. who performed a systematic screening with Doppler ultrasound [5]. As previously reported [2], PE was the leading cause of thrombosis in our cohort. As there is a growing interest in chest $\mathrm{CT}$ scan as a diagnostic tool for SARS-CoV-2 pneumonia [6], performing a systematic pulmonary angiography may constitute a relevant strategy.

Noteworthy, we report on a $21 \%$ rate of significant HE, most of them occurring in patients with full-dose anticoagulation. As half of these patients were treated with full-dose preemptive anticoagulation without a confirmed TE, we must be cautious about our thromboprophylaxis strategy with daily reassessment of its 


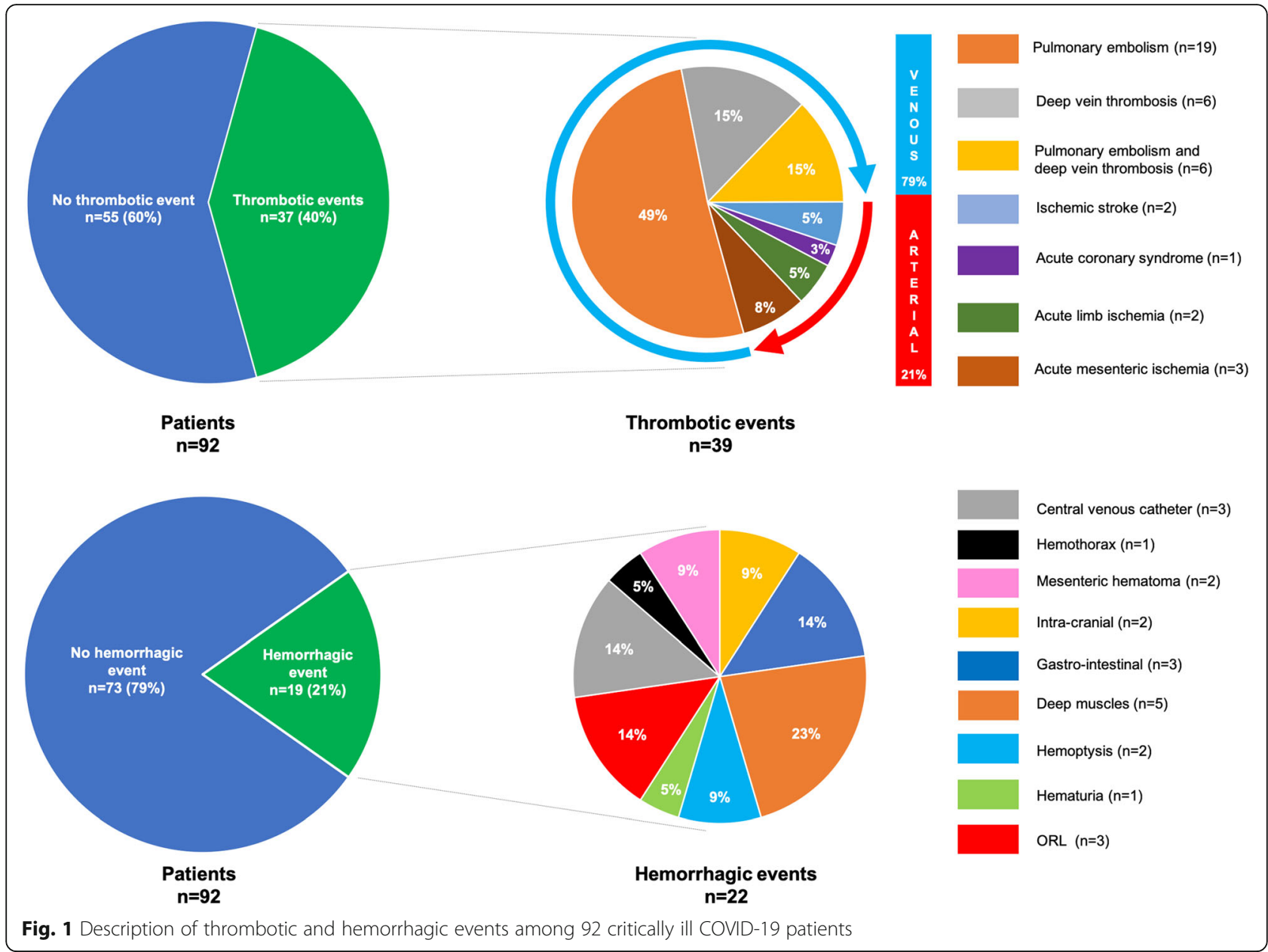

indication. Moreover, it is interesting to note that fulldose anticoagulation did not prevent some patients from developing a TE.

The retrospective monocenter design of our study implies numerous limitations. Nevertheless, we reported on a high rate of TE and HE in ICU COVID19 patients highlighting the necessity to adapt our thrombo-prophylaxis strategy as well as our TE screening strategy.

\section{Abbreviations}

SOFA: Sequential Organ Failure Assessment; SAPSII: Simplified Acute Physiology Score II

\section{Acknowledgements}

None

\section{Authors' contributions}

MF, DC, and GP are responsible for the conception and design. All the authors were responsible for the data acquisition, analysis, and interpretation. All authors read, critically reviewed, and approved the final manuscript. DC takes responsibility for the paper as a whole.

\section{Funding}

No funding
Availability of data and materials

The dataset used and analyzed for the current study is available from the corresponding author on reasonable request.

Ethics approval and consent to participate

This study was conducted in accordance with the amended Declaration of Helsinki and was approved by the Institutional Review Board (CE 20-39) of the French Intensive Care Society.

Consent for publication

Not applicable

Competing interests

The authors declare that they have no competing interests.

Received: 18 May 2020 Accepted: 25 May 2020

Published online: 02 June 2020

\section{References}

1. Cui S, Chen S, Li X, Liu S, Wang F. Prevalence of venous thromboembolism in patients with severe novel coronavirus pneumonia. J Thromb Haemost JTH. 2020

2. Klok FA, Kruip MJHA, van der Meer NJM, Arbous MS, Gommers D A. MPJ, Kant KM, et al. Incidence of thrombotic complications in critically ill ICU patients with COVID-19. Thromb Res. 2020;. 
3. Helms J, Tacquard C, Severac F, Leonard-Lorant I, Ohana M, Delabranche X, et al. High risk of thrombosis in patients with severe SARS-CoV-2 infection: a multicenter prospective cohort study. Intensive Care Med. 2020.

4. Susen S, Tacquard CA, Godon A, Mansour A, Nguyen P, Godier A, et al. Traitement anticoagulant pour la prevention du risque thrombotique chez un patient hospitalise avec covid-19 et surveillance de l'hemostase propositions du GIHP et du GFHT. Available at https://site.geht.org/app/ uploads/2020/04/COVID-19-GIHP-GFHT-3-avril-final.pdf.

5. Llitjos J, Leclerc M, Chochois C, Monsallier J, Ramakers M, Auvray M, et al. High incidence of venous thromboembolic events in anticoagulated severe COVID-19 patients. J Thromb Haemost. 2020; Available from: https:// onlinelibrary.wiley.com/doi/abs/10.1111/jth.14869. [cited 2020 May 9].

6. Fang Y, Zhang H, Xie J, Lin M, Ying L, Pang P, et al. Sensitivity of chest CT for COVID-19: comparison to RT-PCR. Radiology. 2020;200432.

\section{Publisher's Note}

Springer Nature remains neutral with regard to jurisdictional claims in published maps and institutional affiliations.

Ready to submit your research? Choose BMC and benefit from:

- fast, convenient online submission

- thorough peer review by experienced researchers in your field

- rapid publication on acceptance

- support for research data, including large and complex data types

- gold Open Access which fosters wider collaboration and increased citations

- maximum visibility for your research: over $100 \mathrm{M}$ website views per year

At $\mathrm{BMC}$, research is always in progress.

Learn more biomedcentral.com/submissions 